\title{
Cross Cultural Adjustment - A catalyst to enhance psychological well being and work performance of Indian IT expatriates in USA
}

\author{
Dr. Rajeesh Viswanathan, Dr. Moiz Mohammed, Sarath Lal, Dr. Jahira Parveen
}

\begin{abstract}
:
Purpose - The present study is an attempt to analyse the impact of cross cultural adjustment on psychological wellbeing and work performance of the Indian IT expatriates working in the United States of America.
\end{abstract}

Design/Methodology/Approach- This study adopts positivist deductive approach it, starts with clear variables which are derived from theory and based on these variables. The data for the study was collected through the structured questionnaire.

Design/Methodology/Approach- This study adopts positivist deductive approach it, starts with clear variables which are derived from theory and based on these variables. The data for the study was collected through the structured questionnaire. The sample for the present study was collected from the Indian IT expatriates who are assigned to USA working in the four major IT cluster of USA i.e. California, Washington, New York, \& Chicago. A total 634 questionnaires were received indicating a response rate of 52 $\%$. For the current research the questionnaire comprises of 44 items and Likert five poit scale is applied to get the response where formats used for all the measures ranging from strongly agree to strongly disagree. SPSS 21 and Microsoft excel are the statistical packages regression is the tools used in the present study

Findings- A significant relationship was found between cross cultural work adjustment and expatriate psychological wellbeing and work performance. Cross cultural adjustment of the expatriates both to work and general adjustment play an important role in the work performance of the expatriate. A highly adjusted employee performance is better on work than and highly unadjusted employee. When an expatriate is well adjusted to the general environment, the level of psychological wellbeing will be high

Originality/value- This study provides insightful findings in understanding the role of expatriate work and general adjustment in the individual level and work outcomes. This study also shows the importance of the demographic variables with impact expatriate adjustment. In spite of the limitations of the research, the study contributed to the international human resources management by exploring the Indian IT expatriates adaptation process in the western context.

Revised Manuscript Received on July 05, 2019

Dr. Rajeesh Viswanathan, Asst Prof, Dept of International Business, School of Management, Pondicherry University, Pondicherry.

Dr. Moiz Mohammed, Nawab Shah Alam Khan College of Engineering and Technology, Hyderabad, AP, India.

N. Sarath Lal, Dept of International Business, School of Management, Pondicherry University, Pondicherry.

Dr. Jahira Parveen, Faculty of Management, SRM Institute of Technology, Chennai.
Index Terms: Cross Cultural Work Adjustment, Cross Cultural General Adjustment, Psychological Wellbeing and Work Performance.

\section{INTRODUCTION}

Globalization has made the world shrink whereby employees have been moving across the globe as the organizations expand their business outreach to enhance their market share. To facilitate this human resources play a vital role. Increasingly, MNCs have are extensively using expatriates to grow globally. Many MNCs have started operating in India due to the growth in IT industry and due to availability of the highly skilled man power. With globalization business have been expanding in an exponential manner and to support these operations employees have been deputed on both short term and long-term international assignments than ever before as cited in (Hechnova, Beehr, \& Christiansen, 2003). International assignments can be extremely challenging (Hechnova, Beehr, \& Christiansen, 2003).

Though it is of strategic importance of sending an employee onsite abroad, but along with it the company has to invest nearly four to five times as compared to execution of the same activity in India. (Vallabh, Mishra \& Bhaitia, 2008).And if the employee underperform or quite then it will impact the project schedule and it might result in loss for the MNCs in the form of reputation with the client and also monitory losses.

This study focuses on Indian IT expatriates working in the United States of America and their experiences and perceptions of their cross-cultural adjustment, Psychological wellbeing, and work performance.

PD: power distance; INDV: individualism; MA= masculinity; $\mathrm{UA}=$ Uncertainty avoidance; LTO: long term orientation; INDU: Indulgence 


\section{CULTURAL DIFFERENCES BETWEEN INDIA AND UNITED STATES OF AMERICA}

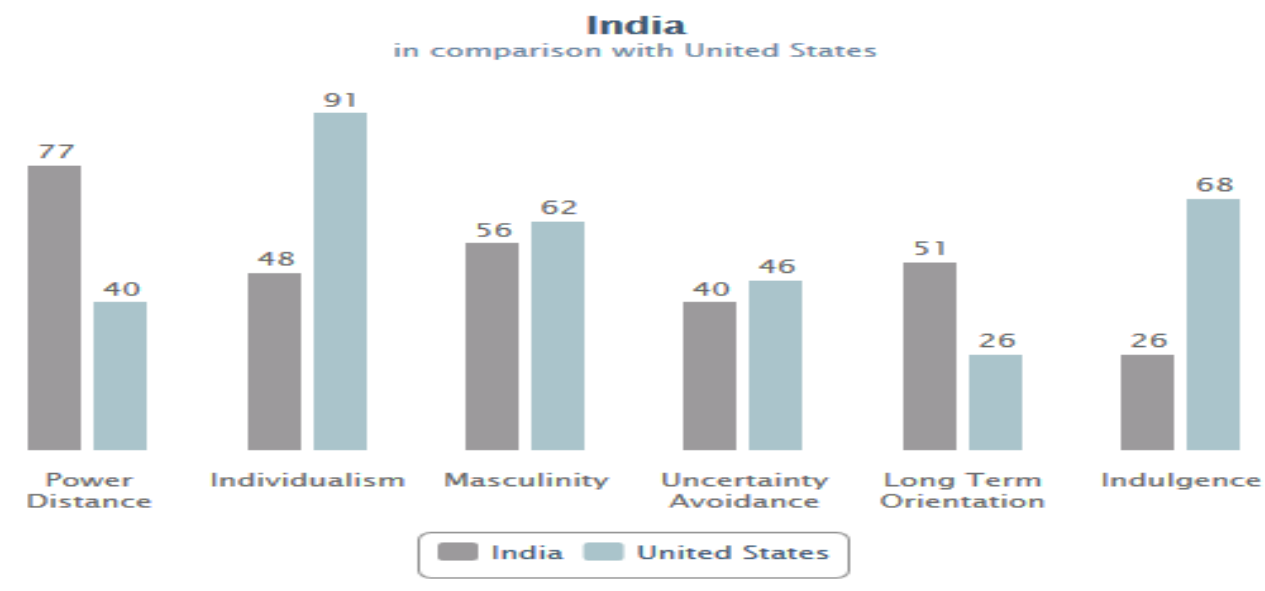

According to Hofstede model, there are clear differences between the India and United States of America on various cultural dimensions. On power dimension, India scored 77 whereas USA scores 40 that mean that in India power distances between the superior and subordinates are larger than the United State of America. Individualism score is 91 in United States of America and in India, the score is only 48, it shows that the American society is more individualistic than the Indian society. Similarly, there are difference on other dimensions like masculinity, Uncertainty avoidance, long term orientation; and Indulgence. Therefore, according to Hofstede model there are substantial differences in terms of socio cultural context between India and United States of America. United States was considered as an appropriate research setting due the above socio cultural differences between India and United States of America. It is important to understand and explore the how Indian IT expatriates adapt to their work environment in the culturally different country and perform effectively.

\section{Cross Cultural Adjustment}

An expatriate has to adapt to new climate both geographical and organizational aspart from the new job responsibilities. Further overcome including the language barrier. (Hechnova, Beehr, \& Christiansen, 2003). "Cross-cultural adjustment is a psychological outcome linked with the way employee associates or adapts to the new environment in all aspects " as cited in (Lin, Chen, \& Song, 2012:543 ). "The cross-cultural adjustment framework developed by Black (1988) consists of three dimensions: namely general, work, and interaction adjustment. General adjustment is associated with factors such as living conditions, facilities, and transportation; interaction adjustment focuses on the extent of socializing with the host country nationals after work; and work adjustment refers to the degree of comfort with work-related factors" as cited in (Wua \& Ang, 2011:2685). (Wua \& Ang, 2011: 2683) argue that "research has found inadequate cross-cultural adjustment to be a key determinant of poor expatriate performance and early repatriation."

\section{Psychological Wellbeing}

With the recent researches, researchers have coined addition to subjective well being such as, Deci and Ryan (e.g., Ryan \& Deci, 2000, 2001) and Ryff (1989) based on the thoughts of universal human desires for effective functioning. It was coined as "psychological well-being" and is based on humanistic theories of positive functioning. The authors stated that it is quiet different from subjective feelings of well-being even if they overlap empirically. Subjective well-being is defined as people's evaluations of their lives, psychological well-being is thought to represent optimal human functioning. Any job can make us feel relaxed and vice versa. Psychological wellbeing facilitates optimistic relationship, conducive working culture and a feel of achievement. Negative relationships with others and work that is demanding "or lacks meaning" damages resilience and psychological wellbeing. Research studies have shown that higher levels of psychological wellbeing are linked to better work performance. Expatriates who are assignment on the foreign assignments due to cross cultural differences might face problems at work that might threaten their psychological wellbeing. Psychological well-being is given much importance in the domestic settings. It's also important to understand Psychological wellbeing expatriates who work in culturally diverse settings.

\section{Job Performance}

Job performance has been defined as "the aggregate value to the organization, of the discrete behavioral episodes that an individual performs over a standard interval of time" (Borman \& Motowildo, 1997). (Borman \& Motowildo, 1997) has divided the Job performance into two distinct dimensions i.e. task performance and contextual performance. "Task performance is concerned with formally defined prescribed behaviors distinct to specific to job that contributes to the organizational technical core" (Borman \& Motowildo, 1997). "Contextual performance include extra role behaviors supporting broader social and 
psychological environments encompassing the technical role of the organization, which are not explicitly included in the list of formal job responsibilities and obligations" (Borman \& Motowildo, 1997). (Osman-Gani \& Rockstuhl, 2009:277) argued that "One of the major determinants of expatriate performance effectiveness is how well they adjust themselves to function appropriately in the host culture." Both task performance and contextual performance are important for the success of the organization and the individual employee performance. Contextual performance assumes an important role in the case of expatriates because it involves social interactions and the expatriates have to adjust to the new culture and the have to work in the culturally diversified workplace.

\section{Purpose OF THe STUdy}

This study focuses on Indian IT expatriates working in the USA and their experiences and perceptions of their cross-cultural adjustment, Psychological wellbeing, and work performance.

\section{RATIONALE}

When an expatriate is assigned to country with is culturally different the expatiate employee may experience cultural difference and this may impact his adjustment to the new environment and it may further impact his psychological wellbeing and the performance. Number of MNCs operating in India sends the employee to the oversea assignments for the undertaking projects. Therefore, there is a need to study the impact of individual level competencies like work adjustment and general adjustment which impact the Indian expatriates working in culturally diverse country like United States of America. This aim of the study is to provide into insights that will help the MNCs in selection and training expatiates for optimal performance and the employee psychological wellbeing and Work Performance

\section{SIGNIFICANCE OF THE STUDY}

On a general level, this study will have significant value for Indian expatriates investing time in United States of America, because this research thoroughly covers past and present cultural and business analysis trends in Saudi Arabia.

1. The findings of this study will provide valuable information for policy makers in the top management of Indian companies to make effective decisions that support and fund effective expatriation programs.

2. This study and its findings will also update international research on Indian expatriation and cross-cultural adjustment, psychological wellbeing job performance

\section{SCOPE OF THE PRESENT STUdY}

This study is confined to the IT industries and the respondents are the Information Technology expatriates assigned to United States of America on short time and long term assignments on client side or in subsidiary offices of the MNC. Impact of cross cultural adjustment on psychological wellbeing and work performance. Hence, the study is confined to the study variables only.

\section{CONCEPTUAL MODEL}

\section{Objectives}

To understand the relationship of work adjustment, general adjustment with work performance and psychological wellbeing of Indian Information technology expatriates in United States of America.

\section{Hypothesis Development}

H1: There is no significant relationship between cross cultural work adjustment and expatriate cross-cultural work performance.

H2: There is no significant relationship between cross cultural general adjustment and expatriate cross-cultural work performance.

H3: There is no significant relationship between cross cultural work adjustment and expatriate psychological wellbeing.

H4: There is no significant relationship between cross cultural general adjustment and expatriate psychological wellbeing.

\section{Research Design}

This study adopts positivist deductive approach it, starts with clear variables which are derived from theory and based on these variables, testable hypothesis were framed and tested. This study uses quantitative approach since all the variables in the study are quantifiable. The data for the study was collected through the structured questionnaire. The study aims to contribute to the literature on expatriate management and international human resource management in general. This study is descriptive in nature. The aim of the study is to find causes and relationships between the variables of interest. The study addresses the descriptive to what extent..? Research question examines the complex phenomenon of expatriate cross cultural adjustment and job performance. Since the study involves larger samples, primary data was collected by using survey method. The objective is to understand the perceived impact of cross cultural adjustment of the expatriates and on their psychological wellbeing and work performance. In order to fulfil the study objectives the study employed appropriate methodology.

\section{Survey Method}

It is one of the method adhered to collect the data using questionnaires or interview techniques for recording the verbal behaviour of respondents (Ghauri \& Gronhaug, 2005). A survey is a measurement process used to collect information during a highly structures interview-sometimes with a human interviewer and other times without (Cooper \& Schindler, 2006). Surveys are especially useful for capturing facts, opinions, behaviors, or attitudes (Maylor \& Blackmon, 2005).Questionnaires, structures interviews are most commonly used tools in survey research design (Maylor \& Blackmon, 2005). Surveys can be quick, inexpensive, efficient, and accurate means of assessing information about the population (Zikmund, 2003). Survey can be useful especially when we want to collect data from a large number of respondents and have limited time for collecting data and when the respondent cannot be reached directly (Maylor \& Blackmon, 2005). Due to the usefulness of survey method

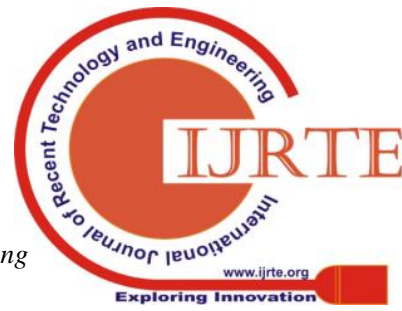


and also based on the previous studies this study adopted survey method to collect the data( see Harrison, \& Shaffer, 2007; Shaffer, Kraimer, Chen, Bolino, \& Chen, 2012). Majority of the researchers used the survey method to carry out the research in cross culturalt context. Therfore this study used survey method to carry out research.

Population and Sample

The sample for the current research consist of Indian IT professional expatriates, working in Indian IT MNC, working on international assignments either at a client site or a branch office in United States of America. In the present study, Indian IT expatriates assigned on the international assignments to United States of America form the sample unit. The sampling technique used for this study is Multistage Random Sampling method (Kothari C.R., 2004).

The sample for the present study was collected from the Indian IT expatriates who are assigned to USA working in the four major IT cluster of USA i.e. California, Washington, New York, \& Chicago. These four states were selected as they were considered the largest IT clusters by the U.S. Cluster Mapping Project. The HR managers of the companies operating in these four regions were approached using networks of the researcher and questionnaires were handed over to the HR managers to be distributed to the Indian IT employees who assigned to the international assignment. The HR managers distributed the questionnaires and collected data and the research collected back the questionnaires from the HR managers of the companies. A total 1200 questionnaires were distributed among the four IT clusters (300 hundred in each cluster) accompanied by a letter emphasizing the confidentiality and anonymity of responses. A total 634 questionnaires were received indicating a response rate of $52 \%$ which is considered a good response rate due to the nature of the study. Out of the 634 questionnaires, received 111 questionnaires were discarded due to missing data. 525 questionnaires were used for the final study. $33 * 33$

$+$

The total sample contained 188 females (40 percent) and 282 males ( 60 percent). The average age of the respondents was 32 years and the minimum qualification was undergraduate (bachelors) degree. Their work experience ranged from 05 to 10 years with the average of 07 years.

Descriptive and analytical research design is used and data were collected from 523 IT expatriates working in USA through structured questionnaire.

\section{Research Tools and Software Package Used}

Research tools are statistical methods used for data analysis and to arrive substantial inferences. SPSS 21, Microsoft Excel are the statistical packages used in the present study and the following statistical tools were used to analyze the data.

\section{Measures}

Cross Cultural Adjustment: Cross cultural adjustment was measure by 10 item work adjustment scale and 9 item general adjustment scale developed by Yu-Ping Chen which was modified and adopted from Black and Stephens, 1989 and Thomas \& Lazarova, 2006. The participants were asked to rate each item on a 5 point- Likert scale from 1(strongly disagree) to 5 (strongly agree). In the current sample, the Cronbach alpha for the instrument was 0.934 for work adjustment and 0.919 for general adjustment

Work Performance: The expatriate performance (Caligiuri, 1997; Motowidlo \& Seotter, 1994).It is a 17 item scale and measures three dimensions namely overall performance, contextual performance and task performance. The participants were asked to rate each item on a 5 pointLikert scale from 1 (strongly disagree) to 5 (strongly agree). In the current sample, the Cronbach alpha for the instrument was 0.919

Psychological Wellbeing: The psychological wellbeing was measured by scale consisting of 8 Items developed by Diener, E., Wirtz, D., Tov, W., Kim-Prieto, C., Choi, D., Oishi, S., \& Biswas-Diener, R. (2009). The participants were asked to rate each item on a 5 point- Likert scale from 1(strongly disagree) to 5 (strongly agree). In the current sample, the Cronbach alpha for the instrument was 0.915

\section{Pilot study}

Pilot testing of the questionnaire was done with Indian IT expatriates those who are working in the United States of America before carrying out the main study. This was to ensure correction of any ambiguities in the measurements as well as capturing correctly the concepts used in the study. Conducting the pilot study the following changes were made to make the questionnaire more understandable and purposeful. Based on the feedback given by the respondents, minor corrections are made in the questionnaire.

\section{Reliability and Validity}

Reliability is the ratio of true variance to the total variance yielded by the measuring instrument. It indicates stability and the internal consistency of a test. The reliability is intended to of a measure the stability and consistency with which the instrument measures the concept and helps to assess the 'goodness' of a measure. A measure is reliable to the degree that it supplier consistent results. Validity is the extent to which the set of measures represent the concept of the study and the degree to which it is free from any random error (Hair, Black, Babin, \&Anderson, 2010). Validity testing refers to as testing the ability of the instrument to measure the particular construct.

\begin{tabular}{|c|l|c|c|c|c|}
\hline S. NO & Constuct & No of Items & $\begin{array}{c}\text { Reliability } \\
\text { (Cronbach's alpha) }\end{array}$ & Composite Reliability & AVE \\
\hline 1 & Work Adjustment & 10 & 0.934 & 0.944 & 0.629 \\
\hline 2 & General Adjustment & 9 & 0.919 & 0.933 & 0.608 \\
\hline 3 & Work Performance & 17 & 0.978 & 0.980 & 0.744 \\
\hline 4 & Psychological wellbeing & 8 & 0.915 & 0.931 & 0.629 \\
\hline
\end{tabular}

The above table displays the value of Cronbach's Alpha coefficient of all the variables in the study of Indian IT expatriates in United States of America. The overall Cronbach's Alpha coefficient is 0.935 , which indicates the high reliability of data. Validity is measured by Average Variance Extracted (AVE). The constructs which has AVE value of above 0.50 possesses convergent validity. In the above table, it can be clearly seen that the AVE values of all the constructs are above 0.50

\section{Normality}

Larger deviations of data form normal distribution affects the results and all the resulting statistics become invalid(Hair, Black, Babin, \& Anderson, 2010). Hence, it is important to test the normality of the data. Normality test are used to check whether the data set is normally distributed. A common rule of normality test is to get the skewness and kurtosis of the data. Skewness instrument is used in distribution analysis as a sign of asymmetry and deviation from a normal distribution. Skewness is the extent to which a variable's

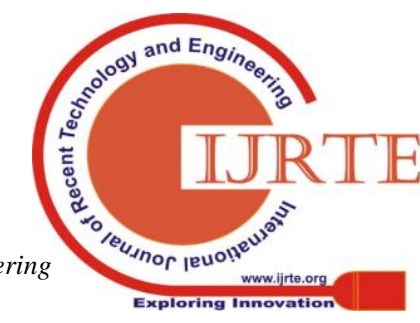


distribution is symmetrically around its mean value. If the data is normally distributes the values of skewness should fall within +2 to -2 range. Kurtosis instrument is used in distribution analysis as a sign of flattening of a distribution. Kurtosis is a measure of whether the distribution is too peaked. The values of kurtosis also should fall within +2 to -2 range when the data are normally distributed.

Skewness and kurtosis

\begin{tabular}{|l|l|l|l|}
\hline \multicolumn{4}{|c|}{ Descriptive Statistics } \\
\hline & $\mathrm{N}$ & Skewness & Kurtosis \\
\hline & Statistic & Statistic & Statistic \\
\hline $\begin{array}{l}\text { Work } \\
\text { Adjustment }\end{array}$ & 523 & -0.575 & -1.222 \\
\hline $\begin{array}{l}\text { General } \\
\text { Adjustment }\end{array}$ & 523 & -0.431 & -1.505 \\
\hline $\begin{array}{l}\text { Work } \\
\text { Performance }\end{array}$ & 523 & -0.315 & -1.527 \\
\hline $\begin{array}{l}\text { Psychological } \\
\text { Wellbeing }\end{array}$ & 523 & -0.54 & -1.265 \\
\hline Valid N & 523 & & \\
\hline
\end{tabular}

From the above table it is absolved that the values of skewness and kurtosis are falling within +2 to -2 range. It means that data of each construct are normally distributed.

\section{Work Adjustment}

Means and Standard deviations are calculated to understand the work adjustment of Indian information technology expatriates in USA.

\begin{tabular}{|c|c|c|c|}
\hline & Item / Variables & Mean & $\begin{array}{c}\text { Std. } \\
\text { Deviation }\end{array}$ \\
\hline WADJ1 & $\begin{array}{ll}\text { Specific } & \text { job } \\
\text { requirements } & \end{array}$ & 3.39 & 1.093 \\
\hline WADJ2 & $\begin{array}{l}\text { Activities or tasks at } \\
\text { work }\end{array}$ & 3.29 & 0.970 \\
\hline WADJ3 & Work hours & 3.29 & 1.068 \\
\hline WADJ4 & Work load & 3.22 & 0.941 \\
\hline WADJ5 & $\begin{array}{l}\text { Communication among } \\
\text { my colleagues }\end{array}$ & 3.40 & 1.063 \\
\hline WADJ6 & $\begin{array}{l}\text { The work attitudes of } \\
\text { employees in the host } \\
\text { country }\end{array}$ & 3.28 & 1.086 \\
\hline WADJ7 & $\begin{array}{l}\text { Skill levels of } \\
\text { employees in the host } \\
\text { country }\end{array}$ & 3.38 & 1.022 \\
\hline WADJ8 & $\begin{array}{l}\text { The corporate Culture of } \\
\text { the host country }\end{array}$ & 3.28 & 1.094 \\
\hline WADJ9 & $\begin{array}{l}\text { Collegiality(relationship } \\
\text { between colleagues ) } \\
\text { among colleagues }\end{array}$ & 3.22 & 1.034 \\
\hline WADJ10 & $\begin{array}{l}\text { Team work among } \\
\text { colleagues }\end{array}$ & 3.28 & 1.029 \\
\hline
\end{tabular}

\section{Mean of Work Performance}

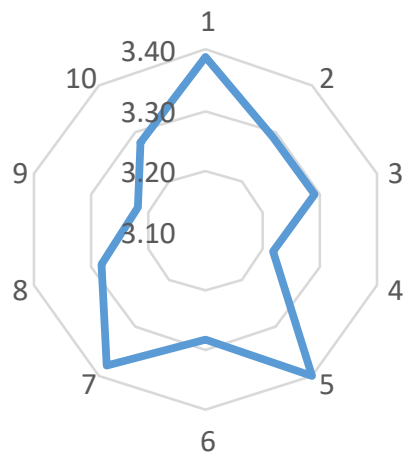

From the above analysis presented in the table, it is observed that overall work adjustment of the Indian information technology expatriates working in United States of America was 3.39 on a scale of 5 indicating above average work adjustment level prevailed among the Indian IT expatriates in USA. It is further observed that mean score range from 3.20 to 3.27 in the data take for the study. The standard deviations for all the variables for work adjustment are almost similar.

\section{General Adjustment}

Means and standard deviations are calculated to understand the general adjustment of Indian information technology expatriates in USA.

\begin{tabular}{|l|l|c|c|}
\hline & \multicolumn{1}{|c|}{ Item / Variables } & Mean & $\begin{array}{c}\text { Std. } \\
\text { Deviation }\end{array}$ \\
\hline GADJ1 & Safety and crime levels & 3.28 & 1.277 \\
\hline GADJ2 & $\begin{array}{l}\text { The cultural } \\
\text { infrastructure }\end{array}$ & 3.28 & 1.231 \\
\hline GADJ3 & $\begin{array}{l}\text { The transportation } \\
\text { infrastructure }\end{array}$ & 3.24 & 1.250 \\
\hline GADJ4 & $\begin{array}{l}\text { Opportunities for leisure } \\
\text { activities }\end{array}$ & 3.28 & 1.231 \\
\hline GADJ5 & $\begin{array}{l}\text { Communication with } \\
\text { non-work host country } \\
\text { nationals }\end{array}$ & 3.31 & 1.265 \\
\hline GADJ6 & $\begin{array}{l}\text { Availability of goods } \\
\text { and services }\end{array}$ & 3.20 & 1.243 \\
\hline GADJ7 & $\begin{array}{l}\text { Availability of medical } \\
\text { care }\end{array}$ & 3.25 & 1.288 \\
\hline GADJ8 & Environmental pollution & 3.26 & 1.294 \\
\hline GADJ9 & $\begin{array}{l}\text { Climate/ weather } \\
\text { conditions }\end{array}$ & 3.33 & 1.263 \\
\hline
\end{tabular}




\section{Mean of General Adjustment}

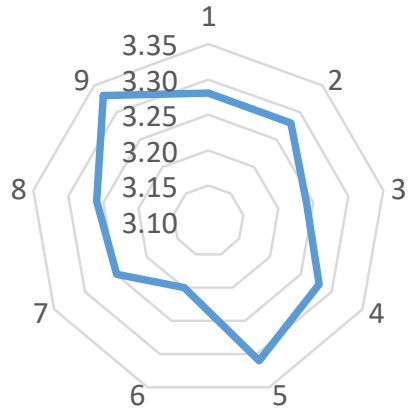

From the above analysis presented in the table, it is observed that overall general adjustment of the Indian information technology expatriates working in United States of America was 3.39 on a scale of 5 indicating above average general adjustment level prevailed among the Indian IT expatriates in USA. It is further observed that mean score range from 3.20 to 3.27 in the data take for the study. The Standard deviations for all the variables for general adjustment are almost similar.

\section{Work Performance}

Means and standard deviations are calculated to understand the work performance of Indian information technology expatriates in USA.

\begin{tabular}{|c|c|c|c|}
\hline & Item / Variables & Mean & $\begin{array}{c}\text { Std. } \\
\text { Deviatio } \\
\mathrm{n}\end{array}$ \\
\hline PREF1 & $\begin{array}{llr}\begin{array}{l}\text { Implementation of the job } \\
\text { responsibilities } \\
\text { other expatriates }\end{array} & & \\
\text { othpared to }\end{array}$ & 3.45 & 1.093 \\
\hline PREF2 & $\begin{array}{l}\text { Contributes ta unit effectiveness } \\
\text { compared to other expatriates }\end{array}$ & 3.37 & 1.152 \\
\hline PREF3 & $\begin{array}{l}\text { Exceeds standards for job } \\
\text { performance compared to other } \\
\text { expatriates }\end{array}$ & 3.46 & 1.068 \\
\hline PREF4 & $\begin{array}{l}\text { Technical performance on this } \\
\text { expatriate assignment compared } \\
\text { to other expatriates }\end{array}$ & 3.45 & 1.129 \\
\hline PREF5 & $\begin{array}{l}\text { Knowledgeable of technical } \\
\text { dimensions of the expatriate } \\
\text { assignment compared to other } \\
\text { expatriates }\end{array}$ & 3.42 & 1.197 \\
\hline PREF6 & $\begin{array}{l}\text { Effectively communicate } \\
\text { technical concepts }\end{array}$ & 3.57 & 1.199 \\
\hline PREF7 & Transfer technical expertise & 3.36 & 1.174 \\
\hline PREF8 & Planning and organizing work & 3.51 & 1.204 \\
\hline PREF9 & $\begin{array}{l}\text { Performing administrative } \\
\text { duties. }\end{array}$ & 3.40 & 1.102 \\
\hline PREF10 & $\begin{array}{l}\text { Effectiveness at maintaining } \\
\text { good working relationships with } \\
\text { host nationals }\end{array}$ & 3.43 & 1.233 \\
\hline PREF11 & $\begin{array}{l}\text { Offer to help others accomplish } \\
\text { their work }\end{array}$ & 3.48 & 1.140 \\
\hline PREF12 & $\begin{array}{l}\text { Support and encourage } \\
\text { colleagues with a problem }\end{array}$ & 3.40 & 1.161 \\
\hline PREF13 & $\begin{array}{l}\text { Cooperate with others in the } \\
\text { team }\end{array}$ & 3.46 & 1.151 \\
\hline PREF14 & $\begin{array}{l}\text { Persist in overcoming obstacles } \\
\text { to complete a task }\end{array}$ & 3.32 & 1.170 \\
\hline PREF15 & Volunteer for additional duty & 3.44 & 1.193 \\
\hline PREF16 & $\begin{array}{l}\text { Exercise personal discipline and } \\
\text { self-control }\end{array}$ & 3.34 & 1.174 \\
\hline PREF17 & $\begin{array}{l}\text { Tackle a difficult work } \\
\text { assignment enthusiastically }\end{array}$ & 3.36 & 1.210 \\
\hline
\end{tabular}

\section{Work Performance}

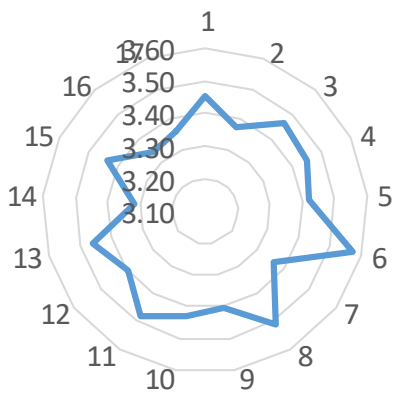

From the above analysis presented in the table, it is observed that overall work performance of the Indian information technology expatriates working in United States of America was 3.39 on a scale of 5 indicating above average work performance prevailed among the Indian IT expatriates in USA. It is further observed that mean score range from 3.20 to 3.27 in the data take for the study. The standard deviations for all the variables for work performance are almost similar.

\section{Psychological Wellbeing}

Means and standard deviations are calculated to understand the psychological wellbeing of Indian technology expatriates in USA.

\begin{tabular}{|c|c|c|c|}
\hline & Item / Variables & Mean & $\begin{array}{c}\text { Std. } \\
\text { Deviation }\end{array}$ \\
\hline PSW1 & $\begin{array}{l}\text { Lead a purposeful and } \\
\text { meaningful life. }\end{array}$ & 3.19 & 0.948 \\
\hline PSW2 & $\begin{array}{l}\text { Social relationships are } \\
\text { supportive } \\
\text { rewarding. }\end{array}$ & 3.24 & 1.116 \\
\hline PSW3 & $\begin{array}{l}\text { Engaged and interested } \\
\text { in my daily activities. }\end{array}$ & 3.17 & 0.953 \\
\hline PSW4 & $\begin{array}{l}\text { Actively contribute to } \\
\text { the happiness and } \\
\text { well-being of others. }\end{array}$ & 3.30 & 1.033 \\
\hline PSW5 & $\begin{array}{l}\text { Competent and capable } \\
\text { in the activities that are } \\
\text { important to me. }\end{array}$ & 3.27 & 0.981 \\
\hline PSW6 & $\begin{array}{l}\text { A good person and live a } \\
\text { good life. }\end{array}$ & 3.15 & 0.910 \\
\hline PSW7 & $\begin{array}{l}\text { Optimistic about my } \\
\text { future. }\end{array}$ & 3.31 & 1.073 \\
\hline PSW8 & People respect me. & 3.23 & 0.968 \\
\hline
\end{tabular}




\section{Psychological Wellbeing}

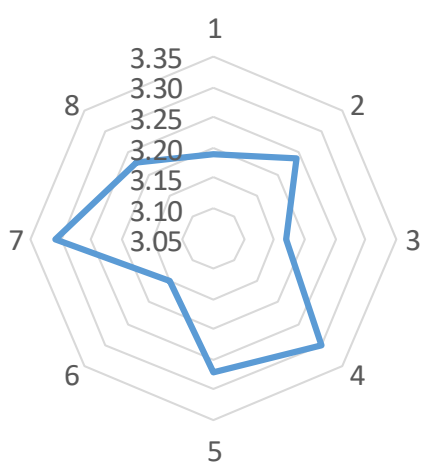

From the above analysis presented in the table, it is observed that overall psychological wellbeing of the Indian information technology expatriates working in United States of America was 3.39 on a scale of 5 indicating above average psychological wellbeing prevailed among the Indian IT expatriates in USA. It is further observed that mean score range from 3.20 to 3.27 in the data take for the study. The standard deviations for all the variables for psychological wellbeing are almost similar.

\section{Multiple Regression Model}

After checking out the positive and strong relationship of cross cultural work and general adjustment on work performance and psychological wellbeing a multiple regression model for various dependent variables in study was developed with the independent constructs like cultural work and general adjustment.

Work Performance predicated by Work Adjustment and General Adjustment

\begin{tabular}{|l|l|}
\hline H1 & $\begin{array}{l}\text { There is no significant relationship } \\
\text { between cross cultural work adjustment } \\
\text { and expatriate cross-cultural work } \\
\text { performance. }\end{array}$ \\
\hline H2 & $\begin{array}{l}\text { There is no significant relationship } \\
\text { between cross cultural general } \\
\text { adjustment and expatriate } \\
\text { cross-cultural work performance. }\end{array}$ \\
\hline
\end{tabular}

\section{Model summary}

\begin{tabular}{|l|l|l|l|l|}
\hline \multicolumn{5}{|c|}{ Model Summary } \\
\hline Model & $\mathrm{R}$ & $\begin{array}{l}\mathrm{R} \\
\text { Square }\end{array}$ & $\begin{array}{l}\text { Adjusted } \\
\text { R Square }\end{array}$ & $\begin{array}{l}\text { Std. Error of the } \\
\text { Estimate }\end{array}$ \\
\hline 1 & $.822^{\mathrm{a}}$ & .675 & .671 & .4449 \\
\hline
\end{tabular}

a. Predictors: (Constant), Work Adjustment, General Adjustment

\section{Interpretations:}

$\mathrm{R}$ is the correlation, its value is 0.822 and $\mathrm{R}$ square is the degree of determination, its value is 0.675 . The degree of determination show the extent to which work adjustment and general adjustment influence work performance. Here the work performance is determined to an extent of $67 \%$ by work adjustment and general adjustment.
Anova Table:

\begin{tabular}{|c|c|c|c|c|c|c|}
\hline \multicolumn{7}{|c|}{ ANOVA $^{2}$} \\
\hline & Made1 & Sum of Squares & $d f$ & Mean Square & F & Sig. \\
\hline \multirow{3}{*}{1} & Regression & 212.072 & 6 & 35.345 & 178.579 & $.000^{2}$ \\
\hline & Residual & 102.130 & 516 & .198 & & \\
\hline & Toxa1 & 314.202 & 522 & & & \\
\hline
\end{tabular}

ANOVA table shows that the significant value is less than 0.01 , which means the dependent variable that is work performance is significantly predicted by the independent variables namely work adjustment and general adjustment at 99\% confidence level.

\begin{tabular}{|c|c|c|c|c|c|c|}
\hline \multicolumn{7}{|c|}{ Coefficients $^{2}$} \\
\hline \multirow{2}{*}{\multicolumn{2}{|c|}{ Model }} & \multicolumn{2}{|c|}{ Unstandardized Coefficients } & \multirow{2}{*}{$\begin{array}{c}\text { Standardized } \\
\text { Coefficients }\end{array}$} & \multirow[t]{2}{*}{$\mathrm{t}$} & \multirow[t]{2}{*}{ Sig. } \\
\hline & & B & Std. Error & & & \\
\hline \multirow{3}{*}{1} & (Constant) & -.325 & .152 & & -2.132 & .033 \\
\hline & Work Adjustment & .101 & .049 & .072 & 2.056 & .040 \\
\hline & General Adjustment & .524 & .050 & .415 & 10.526 & .000 \\
\hline
\end{tabular}

Work Performance $=-0.325+0.101$ (Work Adjustment) +0.524 (General Adjustment)

Among the above two factors general adjustment have a significant and highest impact on the work performance of the Indian IT expatriates in United States of America. Work adjustment significantly contributing to the work performance. Hypothesis [H1] is rejected and shows that is a significant relationship between cross cultural work adjustment and expatriate cross-cultural work performance. Hypothesis [H2] is rejected and shows that there is a significant relationship between cross cultural general adjustment and expatriate cross-cultural work performance.

Psychological wellbeing predicated by Work Adjustment and General Adjustment

\begin{tabular}{|l|l|}
\hline H3 & $\begin{array}{l}\text { There is no significant relationship between cross } \\
\text { cultural work adjustment and expatriate } \\
\text { psychological wellbeing. }\end{array}$ \\
\hline H4 & $\begin{array}{l}\text { There is no significant relationship between cross } \\
\text { cultural general adjustment and expatriate } \\
\text { psychological wellbeing. }\end{array}$ \\
\hline
\end{tabular}

Model Summary

\begin{tabular}{|l|l|l|l|l|}
\hline \multicolumn{5}{|c|}{ Model Summary } \\
\hline Model & $\mathrm{R}$ & R Square & $\begin{array}{l}\text { Adjusted } \\
\text { R Square }\end{array}$ & $\begin{array}{l}\text { Std. Error of the } \\
\text { Estimate }\end{array}$ \\
\hline 1 & $.778^{\mathrm{a}}$ & .605 & .601 & .3461 \\
\hline
\end{tabular}

Interpretations:

$\mathrm{R}$ is the correlation, its value is 0.778 and $\mathrm{R}$ square is the degree of determination, its value is 0.605 . The degree of determination show the extent to which work adjustment and general adjustment influence Work performance. Here the work adjustment is determined to an extent of $60 \%$ by cross cultural work adjustment and cross cultural general adjustment.

\section{Anova Table:}

\begin{tabular}{|c|c|c|c|c|c|c|}
\hline \multicolumn{7}{|c|}{ ANOVA $^{2}$} \\
\hline & Madel & Sum of Squares & $d f$ & Mean Square & $F$ & Sig. \\
\hline \multirow{3}{*}{1} & Regression & 94.824 & 6 & 15.804 & 131.968 & $.000^{2}$ \\
\hline & Residual & 61.794 & 516 & .120 & & \\
\hline & Toxa1 & 156.618 & 522 & & & \\
\hline
\end{tabular}

b. Predictors: (Constant), General Adjustment and Work A djustment

ANOVA table shows that the significant value is less than 0.01 , which means the dependent variable that is work performance is significantly predicted by the

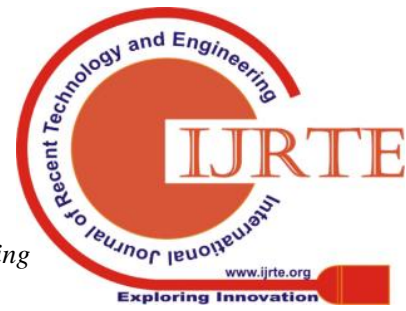


independent variables namely cross cultural work adjustment and cross cultural general adjustment at $99 \%$ confidence level.

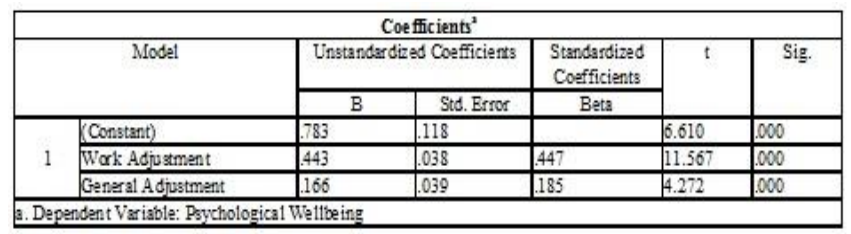

Psychological wellbeing $=0.783+0.443$ (Work Adjust Among the above two factors work adjustment have a significant and highest impact on the psychological wellbeing of the Indian IT expatriates in United States of America. General adjustment significantly contributing to the Psychological wellbeing. Hypothesis [H3] is rejected and its shows that there is a significant relationship between cross cultural work adjustment and expatriate psychological wellbeing. Hypothesis [H4] is rejected and its shows that there is no significant relationship between cross cultural general adjustment and expatriate psychological wellbeing.

\section{Findings}

\begin{tabular}{|c|c|c|}
\hline & Hypothesis & Result \\
\hline H1 & $\begin{array}{l}\text { There is no significant } \\
\text { relationship between cross } \\
\text { cultural work adjustment and } \\
\text { expatriate cross-cultural work } \\
\text { performance. }\end{array}$ & Rejected \\
\hline H2 & $\begin{array}{l}\text { There is no significant } \\
\text { relationship between cross } \\
\text { cultural general adjustment and } \\
\text { expatriate cross-cultural work } \\
\text { performance. }\end{array}$ & Rejected \\
\hline H3 & $\begin{array}{l}\text { There is no significant } \\
\text { relationship between cross } \\
\text { cultural work adjustment and } \\
\text { expatriate } \\
\text { wellbeing. }\end{array}$ & Rejected \\
\hline H4 & $\begin{array}{l}\text { There is no significant } \\
\text { relationship between cross } \\
\text { cultural general adjustment and } \\
\text { expatriate } \\
\text { wellbeing. }\end{array}$ & Rejected \\
\hline
\end{tabular}

A significant relationship was found between cross cultural work adjustment and expatriate cross-cultural work performance.

A significant relationship was found between cross cultural general adjustment and expatriate cross-cultural work performance.

Cross cultural adjustment of the expatriates both to work and general adjustment play an important role in the work performance of the expatriate. A highly adjusted employee performance better on work than and highly unadjusted employee.

A significant relationship was found between cross cultural work adjustment and expatriate psychological wellbeing. When an expatriates is well adjusted to the general environment and the work environment, the level of psychological wellbeing will be high

A significant relationship was found between cross cultural general adjustment and expatriate psychological wellbeing. When an expatriates is well adjusted to the general environment and the work environment, the level of psychological wellbeing will be high

\section{Contribution of the Study}

Majority of the previous studies in the domain of expatriate management have been conducted on the western expatiates who were sent to developing countries as expatriates to work on international assignments. This study contributes to field of international human resources management and expatriate management by focusing on the Indian IT expatriates who are

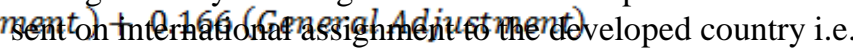
United States of America. This study provides insights on cross cultural adjustment and work performance in cross cultural settings. The MNCs can adopt appropriate strategies to recruit work force which is more compatible to the cross cultural settings and develop global mobile work force, ready to take on international assignment at the short notice which will give comparative advantage to these MNCs. This study gives suggestions to the MNC operating in India strategies for selecting employees who might be sent to work on international assignments. It would help in identifying the right employee for the right assignment and groom them to be successful and effective on the international assignment.

\section{Implications}

When people move across cultures and countries, a global perspective in management theory is critical (Earley \& Ang, 2003).Cultural environment comprises of institutions and other forces that affect society's basic values, perceptions, work ethics, preferences, and behaviors. People grow up in a particular society that shapes their beliefs, values, and behaviors. Culture varies from country to country and these variations result in different behaviors across countries. Work ethics, achievement needs, and effort -reward expectations and values are important cultural factors, having behavioral implications. This study contributes to the theory of culture by findings that shows that cultural intelligence theory developed by (Earley, 2002)(Wu \& Ang, 2011) have important implication for cross cultural adjustment and work performance in cross cultural context.

Based on the analysis of the empirical data and literature the following expatriate staffing implications may be drawn. Incorporating an affective framework into the MNCS, over all human resources management strategies will have positive consequences. The framework is likely to reduce the incidences of ineffective or poor expatriate performance. MNCs can no longer rely solely on technology to gain competitive edge in international markets; they must also rely on international human resources management planning because the organizations and technology are managed and operated by people. Employees chosen to work for the global business possess a basic set of business or technical skills as a prerequisite for the assignment. These people need to complement the basic skills with intercultural competency skills. If they are not able to effectively develop intercultural competency skills, they may not effectively use their business or technical skills.

Strong human resources management leads to greater workforce productivity, improved organizational climate, better employee engagement with the firm and its activities, and other significant benefits. The human resources department should not be neglected or shunted off to a corner office. Good empirical evidence from both 
management and economics fields now strongly show that excellence in HRM leads to excellent employee and firm performance and superior results. Train employees on policies. Also, the MNCs should reward the HR managers who are promoting the policies.

The employees must evaluate the cultural differences that exist between themselves and others as they begin to conduct work in the countries which are culturally different and when they are sent across national borders to work in the host country. The greater the cultural difference, the more crucial it for the employee to understand that key cultural dimensions can influence how their communication and actions perceived. Sensitivity training is useful for preparing managers to address the cultural differences that exist as they conduct business across national borders. The employee must not project their home culture and value system onto others. Projection means that you assume other people think the way you do. In any cross cultural interactions, this is not good assumption to make. This does not mean that employees should abandon their own values when working in another culture. But they should not assume that others share your values and preferences, and will act the way you would.

The firm's managers must design an HRM strategy that promotes the company's overall corporate and business strategies. The cultural nuances inherent in international business heighten the complexities of developing and effective human resource strategy. Managers can use research results and personal observations to develop a character sketch, or cultural profile, of a country. This profile can help managers anticipate how to motivate people and co-ordinate work processes in a particular context. It is Important to recognize that culture is pervasive in business. MNCs that operate in different countries must evaluate their actions in light of cultural differences. Companies need to be sensitive to these problems and provide some support to help expatriates and his family with transitions.

\section{Limitations}

Current study as a series of limitations. In totality most of the limitations of this study are consistent with the limitations of prior empirical studies conducted in the field.

1) Cross Sectional design may hamper the applicability of the causal conclusions drawn from our findings.

2) Also, the study used the self-rater to measure for all constructs and this might not reflect the true picture. It would have been ideal to include supervisor assessment of expatriate performance and adjustment in this study. The study is constrained by not able to collect the data from the spouses regarding their perception about the cross cultural adjustment and international assignment.

3) The study relied on the questionnaire to collected data. Observation and Interview method is could not be carried out in the study because of the geographical distance.

4) The study focused only on IT industry therefore generalization to other expatriates working in other industries should be done with care.

5) There could be bias in the responses as all the responses are based on the perception of the respondents.

\section{Suggestion for Future Research}

Future studies must try to include to collect data from various other sources such as spouses of expatriates and children of the expatriates, colleagues, and supervisors. In the future, more instead of cross sectional study longitudinal studies must be conducted to generate rich data collected over a period of time which will give more insights in the adjustment patterns over a period of time and its impact on work performance, psychological wellbeing. Since the data was collected from the four cities, generalizability of the findings to other expatriates working in worker cities in United States of America is problematic as United States of America is a big country with many sub cultures co existing.

\section{Discussion and Conclusion}

This study explored the influence of individual level factors such as expatriate cross cultural adjustment on psychological wellbeing work performance of the Indian IT expatriates who are assigned to the international assignment in United States of America. As such, it may contribute to the literature on the individual level factors and supporting factors which have an impact on the effectiveness of the expatriates in general, and IT expatriates working in United States of America in particular. Further research is needed for detailed analysis of the effects other important factors such host country nationals support, impact of networks on cross cultural adjustment and on IT expatriates adjustment in United states of America. The findings of the research are in conformation with the views expressed by the researchers in expatriate management and cross cultural management.

Though globalization is forcing the organizations to treats world as a one market, there are large differences exists among the national cultures. An employee who is assigned on an international assignment can succeed without deep understanding of national cultures in which they work. It is important for the employees and the MNCs that understanding a different culture is a never ending process. The employee must prepare themselves by studying more about business etiquette and understanding the national culture. The IT employees must be sensitive and observe the environment and people continuously and adjust their behaviour to work effectively in the host country. They should change the mindset from looking at culture as a potential obstacle and seek opportunity and take advantage of the working in cross cultural settings. The MNCS should train the employees to develop management skills to be successful in more than one culture.

Due to globalization and intense completion on the global IT industry, the MNCS are using international assignments to remain competitive and gain edge over the competitors. The MNCs success and survival depend on its ability to develop technically qualified and self-motivated employees who are capable enough to performance in cross cultural settings. This study shows that the expatriate work performance and psychological wellbeing depends on the expatriate cross cultural adjustment. As predicted, the empirical evidence shows that general adjustment and work adjustment contribute to enhancing expatriates' job performance. This study shows the contribution of the individual competencies like work adjustment and general adjustment on expatriate performance and well being.

\section{REFERENCES}

1. Black, j. S., Amos, T., College, D., \& Hampshire, N. (1988). Coming home: the relationship of expatriate expectations with repatriation adjustment and job performance.

2. Borman, W. C., \& Motowildo, S. J. (1997). A Theory of individual differences in task and contextual performance. 
Human Performance, 10(2), 71-83.

3. Caligiuri, P. M., \& Hyland, M. A. M. (1998). Testing a Theoretical Model for Examining the Relationship Between Family Adjustment and Expatriates' Work Adjustment, 83(4), 598-614.

4. Chen, A. S., Lin, Y., \& Sawangpattanakul, A. (2011). International Journal of Intercultural Relations The relationship between cultural intelligence and performance with the mediating effect of culture shock: A case from Philippine laborers in Taiwan. International Journal of Intercultural Relations, 35(2), 246-258. doi:10.1016/j.ijintrel.2010.09.005.

5. Ghauri, P., \& Gronhaug, K. (2005). Research methods in business studies (3 ed.). England: Prentice Hall Financial Times.

6. Hair, J. F., Black, W., Babin, B. J., \& Anderson, R. (2010), Multivariate data analysis: A global prespective (Seventh ed.). Delhi: Pearson.

7. Harrison, D. A., Shaffer, M. A., Harrison, D. A., \& Shaffer, M. A. (2007). Mapping the criterion space for expatriate success : task- and relationship-based performance, effort and adaptation success : taskand relationship-based, 5192(September 2015). doi:10.1080/09585190500220648.

8. Hechanova, R., Beehr, T. A., \& Christiansen, N. D. (2003). Antecedents and Consequences of Employees Adjustment to Overseas Assignment: A Meta-analytic Review, 52(2), 213-236.

9. Heijden, J. A. V. Van Der, Engen, M. L. Van, \& Paauwe, J. (2015). Expatriate career support: predicting expatriate turnover and performance, 5192(September). doi:10.1080/09585190902770745.

10. Hofstede, G. (1980). Motivation, Leadership, and Organization: Do American Theories Apply Abroad ?

11. Hofstede, G. (2006). What did GLOBE really measure? Researchers ' minds versus respondents , minds, 882-896. doi:10.1057/palgrave.jibs.8400233.

12. Kothari, C. R., \& Garg, G. (2013). Research Methodology. New Delhi, India: New Age International Publishers.

13. Maylor, H., \& Blackmon, k. (2005). Researching business and management. London: Palgrave macmillian.

14. Osman-gani, A. M., \& Rockstuhl, T. (2008). Antecedents and Consequences of Social Network Characteristics for Expatriate Adjustment and Performance in Overseas Assignments : Implications for HRD, 7(1), 32-57. doi:10.1177/1534484307312182.

15. Shaffer, M. A., Kraimer, M. L., Chen, Y., Bolino, M. C., \& Chen, Y. (2012). Review and Future Agenda and Future Agenda. doi:10.1177/0149206312441834.

16. Wu, P., \& Ang, S. H. (2011). The impact of expatriate supporting practices and cultural intelligence on cross-cultural adjustment and performance of expatriates in Singapore, 5192(September 2015). doi:10.1080/09585192.2011.599956.

17. Zikmund, G. W. (2003). Business research methods. New Delhi:

CENGAGE learning . 